\title{
Sedimentology of lower Pliocene to Upper Pleistocene diamictons from IODP Site U1358, Wilkes Land margin, and implications for East Antarctic lce Sheet dynamics
}

\author{
NADINE OREJOLA ${ }^{1}$, SANDRA PASSCHIER ${ }^{1 *}$ and IODP EXPEDITION 318 SCIENTISTS \\ ${ }^{1}$ Department of Earth and Environmental Studies, Montclair State University, 1 Normal Ave, Montclair, NJ 07043, USA \\ *Corresponding author: passchiers@mail.montclair.edu \\ $\dagger$ For a full list of authors see http://publications.iodp.org/proceedings/318/staff.htm
}

\begin{abstract}
During the early Pliocene a dynamic marine-based ice sheet retreated from the Wilkes Land margin with periodic ice advances beyond Last Glacial Maximum position. A change in sand provenance is indicative of a more stable Mertz Glacier system during the Late Pleistocene. East Antarctic Ice Sheet (EAIS) dynamics were evaluated through the analysis of marine diamictons from Integrated Ocean Drilling Program (IODP) site U1358 on the Adélie Land continental shelf. The warmer than present conditions of the early Pliocene coupled with the site's proximity to the landward sloping Wilkes Subglacial Basin provided the rationale for the investigations at this site. Based on visual core descriptions, particle size distributions, and major and trace element ratios, we interpret the origin of lower Pliocene strata by intermittent glaciomarine sedimentation with open-marine conditions and extensive glacial advances to the outer shelf. Heavy mineral analyses show that sand-sized detritus in the lower Pliocene strata was sourced from local intermediate to high-grade metamorphic rocks near Mertz Glacier. In contrast, Pleistocene diamictons exhibit a larger contribution from a prehnite-pumpellyite greenschist facies suggesting supply via iceberg rafting from northern Victoria Land. From this sedimentological evidence, we postulate a shift from a dynamic EAIS margin in the early Pliocene to possible stabilization in the Pleistocene.
\end{abstract}

Received 23 January 2013, accepted 12 June 2013, first published online 13 August 2013

Key words: continental shelf, geochemistry, heavy minerals, particle size, provenance

\section{Introduction}

Integrated Ocean Drilling Program (IODP) "Wilkes Land" Expedition 318 collected seven marine sediment cores from sites off the Terre Adélie and George V Coast during the summer of 2010 (Fig. 1). The objective was to reconstruct East Antarctic Ice Sheet (EAIS) behaviour during climate fluctuations from the Eocene epoch to present-day as an analogue for ice sheet behaviour in response to future global climate changes (Escutia et al. 2011).

Located offshore from the Wilkes Subglacial Basin, the margin was deemed an ideal location for investigations of ice sheet dynamics because the ice sheet is grounded below sea level and therefore possibly sensitive to ocean and surface warming. On the continental shelf west of Mertz Bank, two sediment cores from hole U1358 were retrieved using the rotary core barrel system (RCB). Core U1358B was the more successful of the two that retrieved marine and glacial sediment down to $35.6 \mathrm{~m}$ below sea floor (b.s.f.) (Expedition 318 Scientists 2011). A multichannel seismic reflection profile revealed a significant unconformity (WL-U8) at c. $165 \mathrm{~m}$ b.s.f. (Fig. 1), believed to indicate a change in glacial thermal regime in the mid- to late Miocene (Escutia et al. 2005), however, WL-U8 was not reached during drilling (Expedition 318 Scientists 2011).
Site U1358 is located in the Mertz trough, between the Adélie and the Mertz banks, on the continental shelf off the Adélie Coast at $499 \mathrm{~m}$ below sea level (m b.s.l.) (Fig. 1). The sea floor in the Mertz Trough displays a megaflute morphology indicative of ice advance by the Mertz Glacier to an outer shelf position just landward of site U1358 most likely during the Last Glacial Maximum (LGM) (Domack 1982, Beaman \& Harris 2003). Today and in the past, shelf currents and iceberg scouring in water shallower than $500 \mathrm{~m}$ have modified the diamictons outcropping at the sea floor on the George V shelf (Beaman \& Harris 2003). Seismic profiles show that sometime between the mid-late Miocene and the LGM the ice sheet oscillated with glacial advances to the shelf break and extended beyond the LGM position (Escutia et al. 2005).

IODP site U1358B provides a unique opportunity to assess a portion of this older record, specifically, to reconstruct early Pliocene-Late Pleistocene ice sheet dynamics at an EAIS-proximal site. The objective of this paper is to: i) observe and describe variations in diamicton depositional processes using particle size distribution analysis, ii) investigate diamicton provenance and source terrains by conducting heavy mineral analyses, and iii) summarize changes in chemical weathering, sediment recycling, and biogenic productivity from the early 


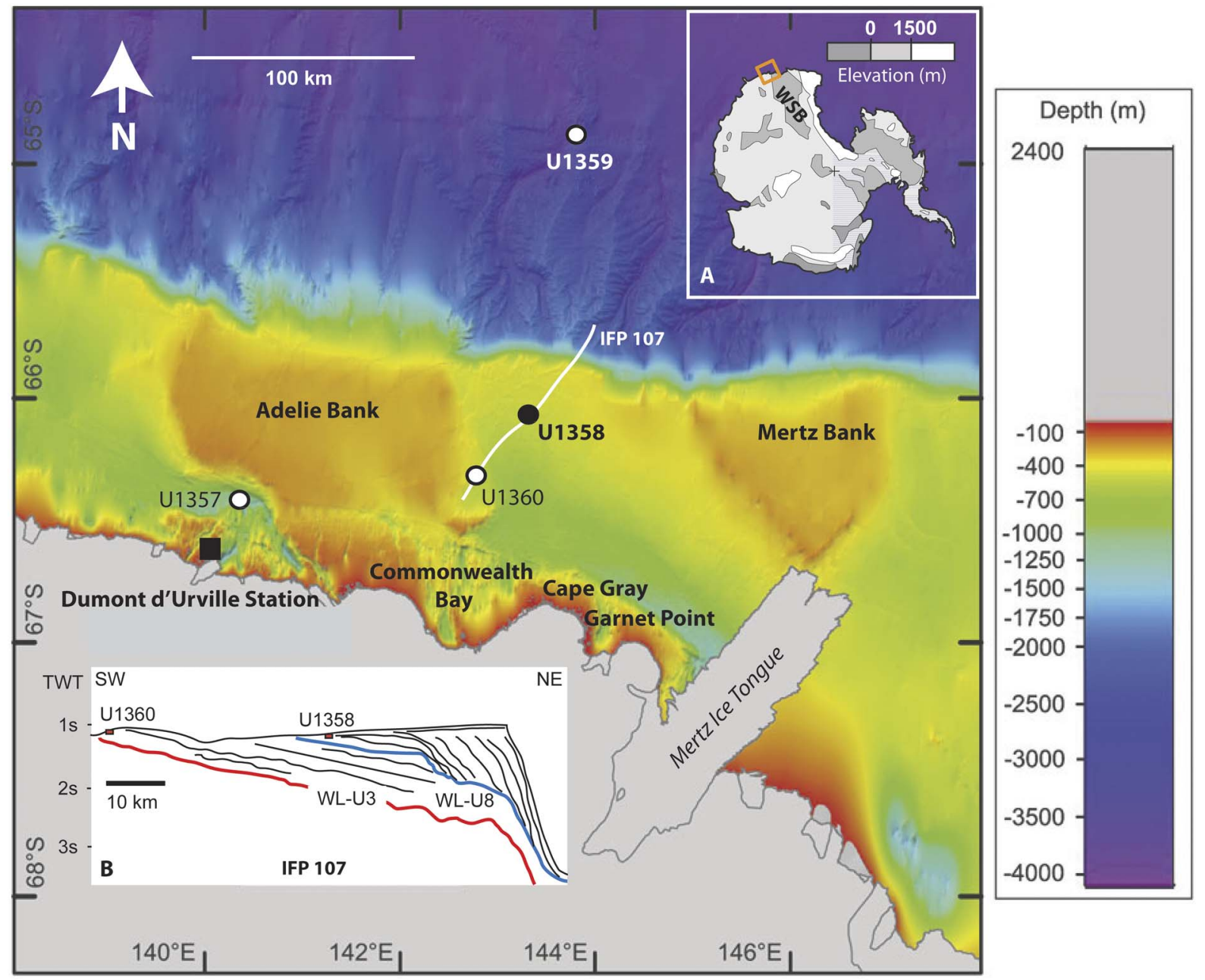

Fig. 1. Four of the seven Integrated Ocean Drilling Program (IODP) Expedition 318 site locations on the George V continental shelf and rise. Site U1358 on the continental shelf is the focus of this paper (modified from Beaman et al. 2011). Inset A: simplified bed topography (after Fretwell et al. 2013), WSB = Wilkes Subglacial Basin. The study area is indicated by a red square. Inset B: line drawing of Oligocene and younger sequences above unconformity WL-U3 in seismic line IFP 107 (cf. Escutia et al. 2005).

Pliocene-Late Pleistocene. The compiled data from the three experiments were used to address the fundamental questions of ice sheet stability and drainage patterns on the Wilkes Land margin during this critical time of warming in the Southern Ocean (Whitehead \& Bohaty 2003, Escutia et al. 2009).

\section{Materials and methods}

Cores from hole U1358B were described on-board ship through visual description of the cut face of the archive half (Expedition 318 Scientists 2011; Fig. S1, which will be found at http://dx.doi.org/10.1017/S0954102013000527). Core $1 \mathrm{R}$ consists of unconsolidated light brownish grey massive clast-rich muddy diamicton with trace abundances of diatoms. Cores $2 \mathrm{R}-4 \mathrm{R}$ consist of consolidated greenish grey to grey massive to crudely stratified clast-rich sandy and muddy diamicton (Fig. 2). A distinct colour change from greenish grey to grey was observed between cores $2 \mathrm{R}$ and $3 \mathrm{R}$. Below $20.45 \mathrm{~m}$ b.s.f. the diamicton is sparsely stratified with planar horizontal to inclined beds and laminations. The diamictons contain between $5 \%$ and $7.5 \%$ clasts up to $24 \mathrm{~cm}$ in diameter (Fig. 2). Clast lithologies include facetted basalt and fine-grained metasediments, and polished granitic gneiss and quartzite, all with subangular to subrounded shape. Hole U1358B yielded 23 diamicton samples that were processed for laboratory analyses at Montclair State University (Montclair, NJ, USA).

\section{Particle size analysis}

A Malvern Mastersizer 2000 laser particle sizer was used to analyse grain size distributions and to determine the dominant diamicton sedimentation process on the Wilkes 

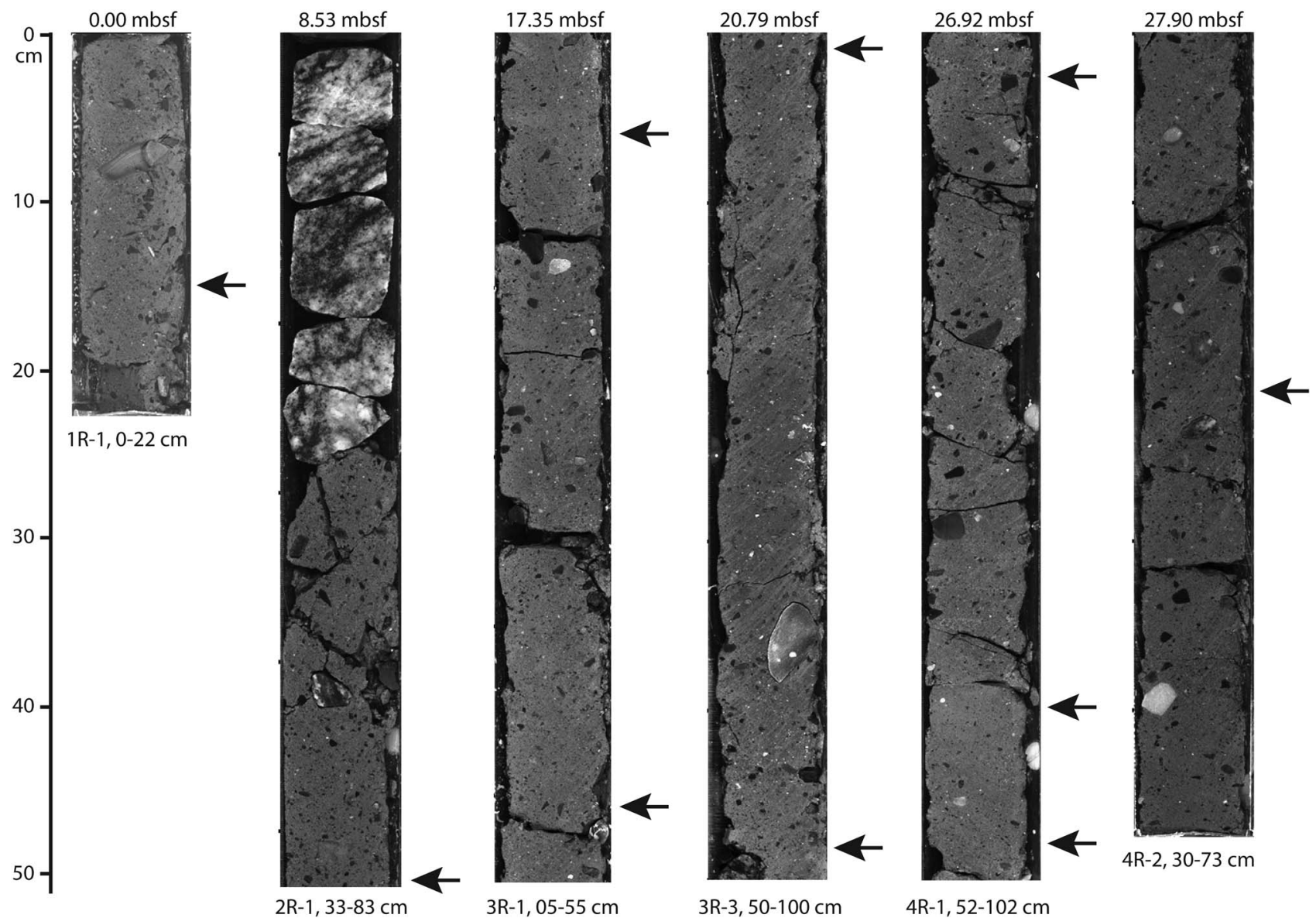

Fig. 2. Core photographs of representative core sections. Arrows indicate sample locations. Depth in meters below sea floor (m b.s.f.) for the top of the core intervals are shown. Core numbers and offset in $\mathrm{cm}$ can be found at the bottom of each photograph. Of note are the large rock clast in interval $2 \mathrm{R}-1,33-83 \mathrm{~cm}$, the massive and homogenous nature of the diamictons in interval $3 \mathrm{R}-1,5-55 \mathrm{~cm}$, the inclined stratification in $3 \mathrm{R}-3,50-100 \mathrm{~cm}$, and the horizontal stratification in interval $4 \mathrm{R}-1,52-102 \mathrm{~cm}$.

Land margin continental shelf. Based on the amount of available sample material, 21 of the 23 samples from hole U1358B were prepared for sediment particle size analysis (Konert \& Vandenberghe 1997, Sperazza et al. 2004). Samples were prepared four at a time using $30 \%$ hydrogen peroxide to disaggregate the sediment and then boiled with deionized (DI) water and $10 \% \mathrm{HCl}$ on a hot plate to remove carbonate and organic material. The disaggregated samples were centrifuged at 1500 rotations per minute $(\mathrm{rpm})$ for $30 \mathrm{~min}$ and the supernatant liquid was removed from the centrifuge tubes. Sodium pyrophosphate was added as a dispersant and the samples were heated for complete dissolution of the dispersant. Once the samples were cooled, they were analysed on the laser particle sizer using a laser obscuration of $20-40 \%$. Particle size distribution histograms were generated and raw data was utilized in the calculation of fractal dimensions with the purpose of determining changes in down core diamicton formation processes (Hooke \& Iverson 1995, Licht et al. 1999, Benn \& Gemmell 2002, Principato et al. 2005).

\section{Geochemical analysis}

Major and trace element geochemical analyses of the matrix of 20 samples were carried out using a Jobin-Yvon ULTIMA C inductively coupled plasma optical emission spectrometer (ICP-OES; HORIBA Jobin Yvon Inc, Edison, NJ, USA). The fine fraction $(<63 \mu \mathrm{m})$ was isolated from bulk samples through standard wet-sieving with a rubber spatula and deionized water to break up the matrix. The fine fraction $(<63 \mu \mathrm{m})$ and coarse fraction $(63-250 \mu \mathrm{m})$ were placed in ceramic bowls, dried at $75^{\circ} \mathrm{C}$ overnight, and transferred into vials. Sample preparation for ICP-OES analysis followed Murray et al. (2000) and was carried out on the fine fraction $(<63 \mu \mathrm{m})$. Approximately $0.1 \mathrm{~g}$ of sample and $0.4 \mathrm{~g}$ of Lithium Metaborate flux $\left(\mathrm{LiBO}_{2}\right)$ were mixed together and carefully transferred to graphite crucibles, which were placed in a furnace at $1050^{\circ} \mathrm{C}$ for 30-40 min. When removed from the furnace, samples were transferred into Teflon beakers with magnetic stir bars and $50 \mathrm{ml}$ of $7 \%$ nitric acid and placed on a magnetic stir plate 


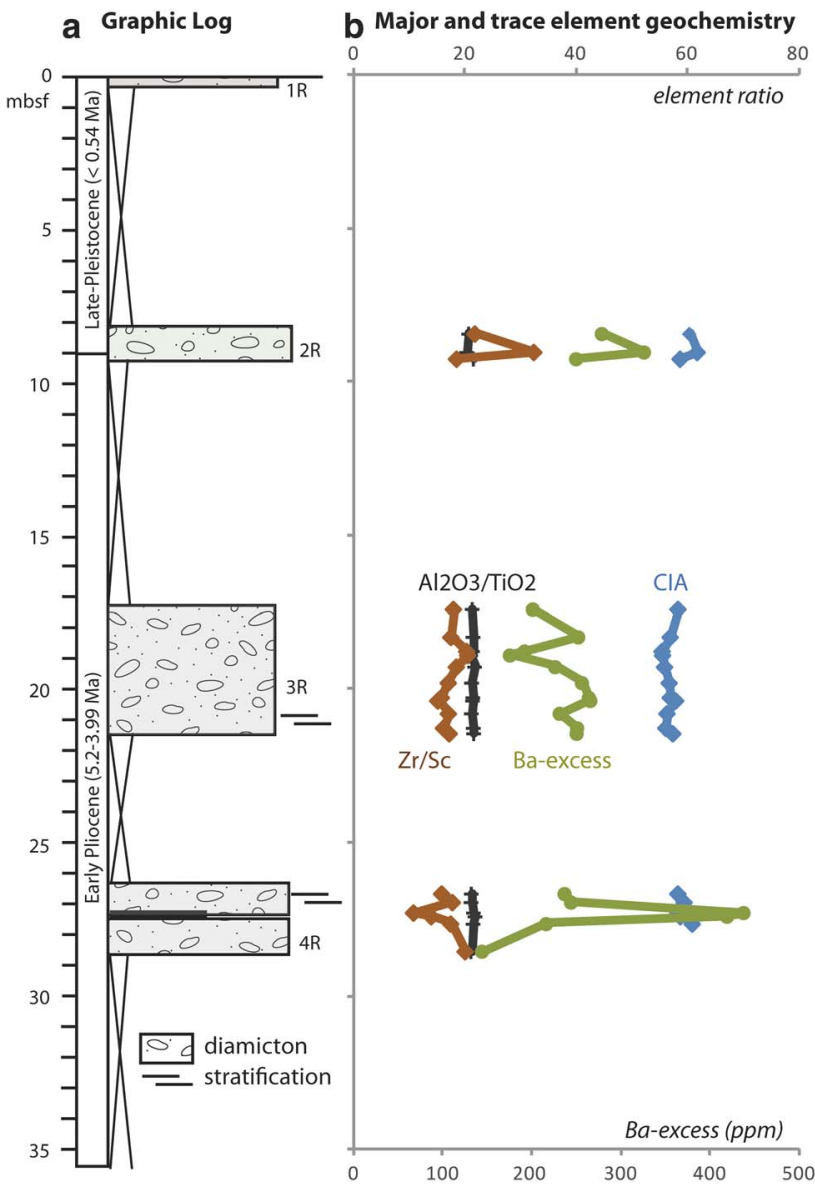

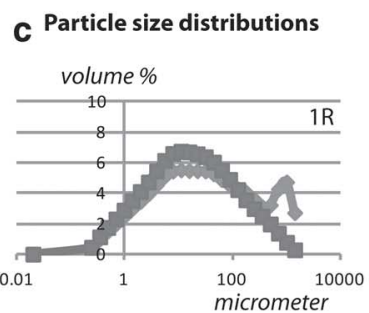
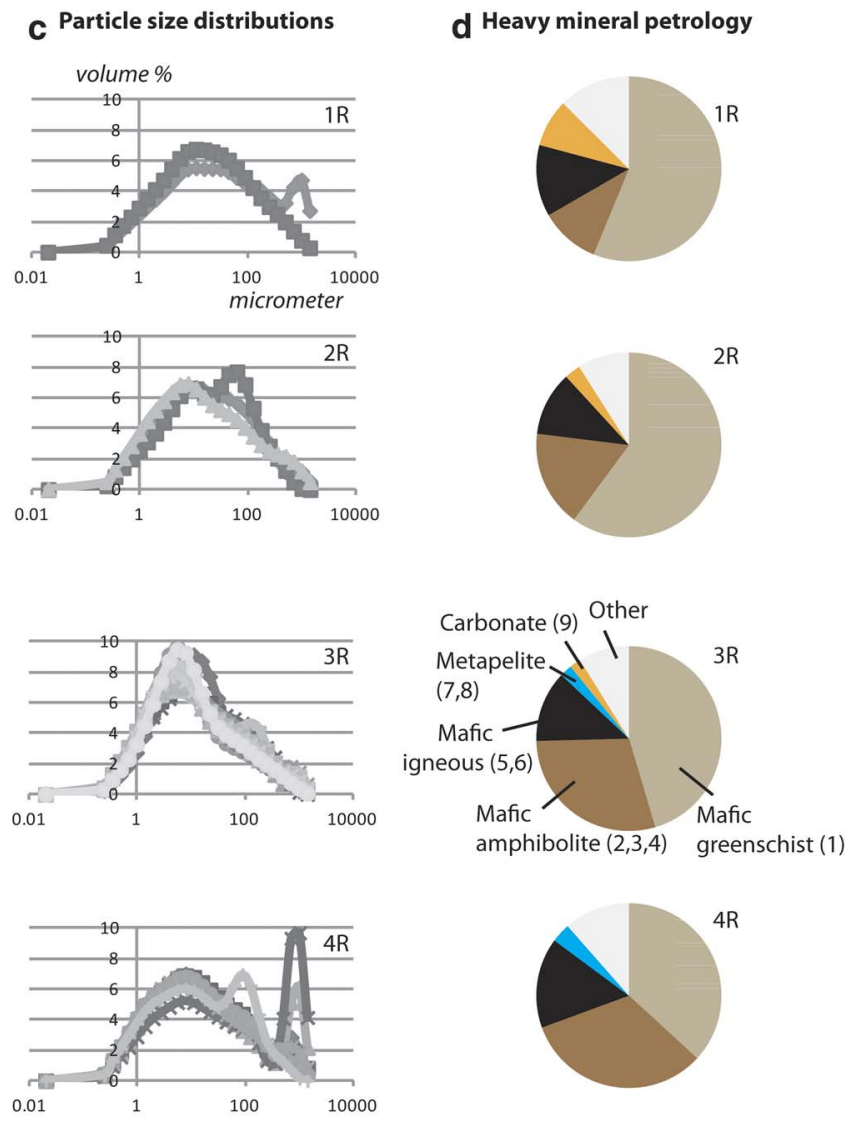

Fig. 3. Downcore distributions of a. lithologies, b. major and trace element geochemistry, c. particle size distributions, and d. heavy mineral petrology for Integrated Ocean Drilling Program (IODP) hole U1358B. In d. numbers in brackets refer to mineral assemblages and source terrains reported in Table S3, which will be found at http://dx.doi.org/10.1017/S0954102013000527.

until the sample was dissolved. Once dissolved, it was poured over a filter into a sample bottle and placed in a refrigerator. Immediately before measurement on the ICP-OES, the samples, along with 12 USGS standards for calibration, were diluted using $2 \%$ nitric acid.

The ICP-OES geochemical data (Tables S1 \& S2, which will be found at http://dx.doi.org/10.1017/S0954102013 000527) is represented as element ratios (Fig. 3b). To infer the degree of chemical weathering, the chemical index of alteration (CIA) was calculated with a correction for the presence of biogenic and terrigenous carbonate (Nesbitt \& Young 1982). To assess sediment recycling we used $\mathrm{Zr} / \mathrm{Sc}$ ratios, which are high for mature marine sediments on passive continental margins (McLennan et al. 1993). $\mathrm{TiO}_{2} /$ $\mathrm{Al}_{2} \mathrm{O}_{3}$ ratios are primarily controlled by rock provenance and vary widely in soils developed on mafic vs felsic igneous source rocks (Nesbitt \& Young 1996). We calculated Ba-excess values to assess marine palaeoproductivity (Schenau et al. 2001). For the calculation of the Ba-excess values the lithogenic $\mathrm{Ba}$ component was derived from the average whole-rock composition of clasts collected in dredges near the Mertz Glacier tongue (Goodge \& Fanning 2010). The clasts are probably derived from Mertz Glacier and are assumed to be a representative sampling of the local bedrock, which is largely inaccessible due to the presence of the ice.

\section{Heavy mineral analysis}

A Hitachi scanning electron microscope (SEM) S-3400N with Bruker electron dispersive spectroscopy (EDS) system was used to determine the mineralogical variety in the sand fraction of 18 samples that were chosen based on the amount of available coarse fraction. Heavy minerals were separated by pouring the entire fine sand fraction (63-250 $\mu \mathrm{m}$ sieve residue) into $50 \mathrm{ml}$ centrifuge tubes filled with heavy liquid (sodium polytungstate; $2.89 \mathrm{~g} \mathrm{c} \mathrm{m}^{-3}$ ). The centrifuge tubes were rotated for $15 \mathrm{~min}$ at $3000 \mathrm{rpm}$ and when completed, dry ice was used to freeze the tips of the tubes to isolate the heavy minerals while pouring the lighter minerals through a filter. The remaining heavy mineral grains were filtered out, cleaned with deionized water, 

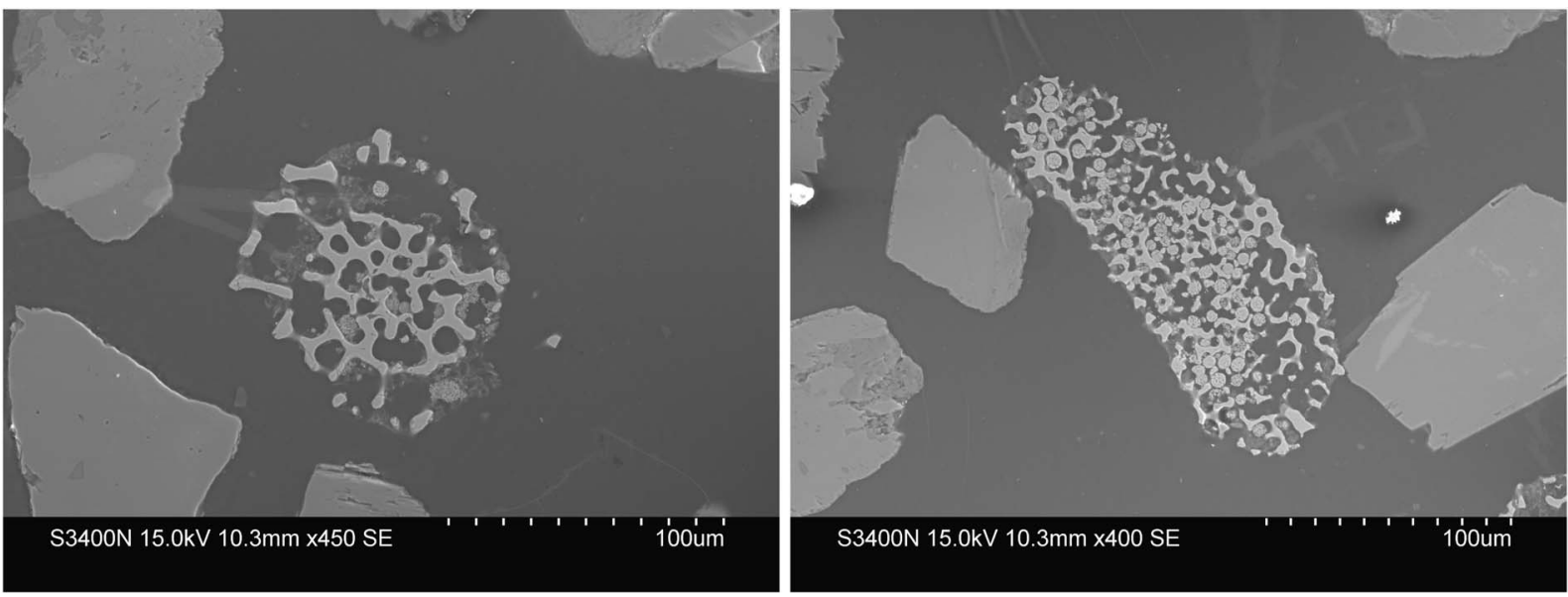

Fig. 4. SEM images of polished grains of pyritized biogenic fragments in sample U1358B-2R1-83-85 $\mathrm{cm}$ at $c$. $9.03 \mathrm{~m}$ b.s.f. This sample also displayed slightly elevated $\mathrm{Ba}$-excess and $\mathrm{Zr} / \mathrm{Sc}$ ratios for the bulk mud fraction and a sand mode in the particle size distributions (Fig. 3b).

dried, weighed, and placed in 18 separate wells drilled in two lucite discs (nine wells per disc) using tape for the grains to adhere and prevent extraneous material from entering the specified wells. The wells were then filled with a 5:1 ratio of epoxicure resin and hardener. The analytical sides of the sample discs were diamond polished, then carbon coated and analysed at $15.0 \mathrm{keV}$ with a $c .10 \mathrm{~mm}$ working distance. Thirty-five grains per sample were randomly selected for standardless EDS analysis. Electron dispersion spectra were compared to characteristic mineral spectra published by Reed (2005). Optical microscope analysis assisted in the identification of garnet and gedrite grains (Deer et al. 1992). Major elemental oxide weight percentages (wt $\%$ ) with an accuracy of $10 \%$ for oxides with $>2 \mathrm{wt} \%$ abundances were determined using Esprit 1.9 software (Bruker). Compositions of pyroxenes and amphiboles were recalculated back to cation proportions using mineral formulae recalculation spread sheets from http://serc.carleton.edu/ and plotted on quadrilateral diagrams.

\section{Results}

\section{Particle size distributions}

Particle size distributions are variable and both bi-modal and uni-modal for cores $4 \mathrm{R}, 2 \mathrm{R}$, and $1 \mathrm{R}$, whereas the distributions for core $3 \mathrm{R}$ are more uniform and uni-modal (Fig. 3c). Fractal distribution values for all samples were between 3.0 and 3.5, with $r^{2}$ between 0.97 and 0.99 (Fig. S2, which will be found at http://dx.doi.org/10.1017/ S0954102013000527). Despite this dominant trend, two samples from core $4 \mathrm{R}$ at $27.4 \mathrm{mb}$ b.s.f. and $27.28 \mathrm{mb}$.s.f. within stratified diamictons interbedded with mudstones displayed distinct coarse sand enrichments expressed as humps in both the fractal plots and the grain-size histograms.

\section{Geochemical analysis}

$\mathrm{Al}_{2} \mathrm{O}_{3} / \mathrm{TiO}_{2}$ ratios vary between 20.43 and 21.96 and support a uniform intermediate to felsic provenance for the

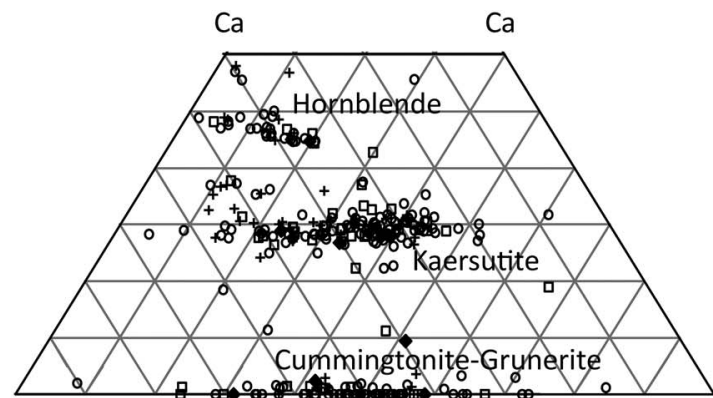

$\mathrm{Mg}$

Amphiboles

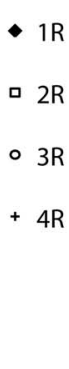

$\mathrm{Fe}$

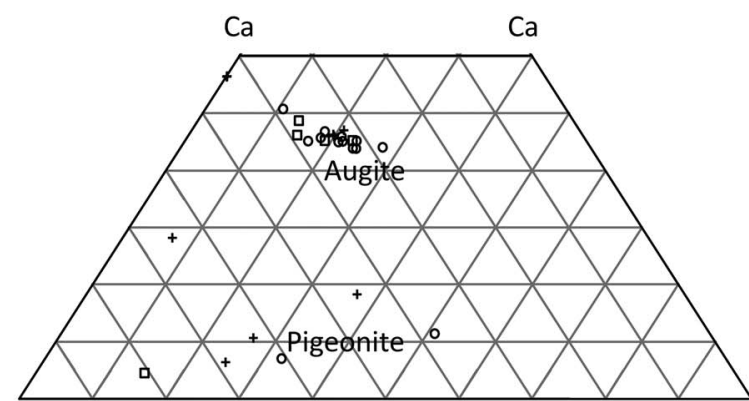

Pyroxenes
$\mathrm{Fe}$

Fig. 5. Recalculated cation proportions of $\mathrm{Ca}, \mathrm{Mg}$, and $\mathrm{Fe}$ of amphibole and pyroxenes plotted on quadrilateral diagrams. Symbol labels refer to core numbers $(1 \mathrm{R}-4 \mathrm{R})$ in hole $\mathrm{U} 1358 \mathrm{~B}$. 
fine sediment fraction. Carbonate percentages were measured shipboard on sediment samples in cores $1 \mathrm{R}, 3 \mathrm{R}$ and $4 \mathrm{R}$ and yielded 2.8, 2.6 and $3.4 \mathrm{wt} \%$. The CIA ranged between 56 and 62 with one outlier sample in the core catcher at the base of hole U1358B yielding a CIA of 52 associated with exceptionally high $\mathrm{CaO}$ concentration (3.84 $\mathrm{wt} \%$ ). An outlier in $\mathrm{Zr} / \mathrm{Sc}$ values was observed for one sample in core $2 \mathrm{R}$ at $9.03 \mathrm{~m}$ b.s.f., which also had an elevated Ba-excess ratio and a slightly elevated CIA of 62. Ba-excess values were the highest, however, in two samples in core $4 \mathrm{R}$ (Fig. 3b).

\section{Heavy mineral analysis}

Single mineral grains and minerals of rock fragments were assigned to consistent petrological assemblages that had been identified down-core. Pie diagrams were generated to provide a detailed representation of down-core variations in the relative abundance of rock types and protoliths in U1358B (Fig. 3d). Based on their co-occurrence in rock fragments, nine distinct petrological assemblages are distinguished, ranging from various grades of metamorphism with mafic/ intermediate and mafic protoliths as well as a mafic dyke signature and a metamorphosed carbonate signature (Table S3, which will be found at http://dx.doi.org/10.1017/ S0954102013000527). Other minerals not classified include monazite and pyritized biogenic clasts (Fig. 4). The quadrilateral diagrams reveal uniform down-core distribution of amphiboles such as kaersutite, actinolite, hornblende, and cummingtonite/grunerite and a few Ca-rich and Fe-rich pyroxenes (Fig. 5).

\section{Discussion}

\section{Depositional model}

The grain-size distributions (Fig. 3c) and fractal dimensions (Fig. S2, which will be found at http://dx.doi.org/10.1017/ S0954102013000527) of all 21 diamicton samples are characteristic of a source region dominated by glacial processes with an increase in the production of finer material through grain slippage and abrasion, and/or subglacial reworking of pre-existing (glacio) marine sediments (Hooke \& Iverson 1995, Benn \& Gemmel 2002). The glacigenic origin for the diamictons recovered in hole U1358B is confirmed by the bulk major element analysis, which shows relatively low CIAs (56-62) indicative of parent rocks that are chemically unweathered (Nesbitt \& Young 1982).

Preliminary shipboard investigations concluded that the diamictons in the upper $\sim 9 \mathrm{mb}$.s.f. (core $1 \mathrm{R}$ and section 2R-1) and those, which are crudely stratified and interbedded with muds (below $20.45 \mathrm{mb}$ b.s.f.), were deposited from floating ice (Licht et al. 1999). The stratification in sections 3R-3 and 4R-1 (Fig. 2) did not show evidence of boudinage or other characteristics typical of glaciotectonic laminations and were hence attributed to current activity. In agreement with this, the diamictons in cores $1 \mathrm{R}$, and the upper portions of cores $2 \mathrm{R}$ and $4 \mathrm{R}$ show some enrichment of sand and some sorting (Fig. 3c). The coincidence of (non-glaciotectonic) planar laminations, mud interbeds, and unconsolidated diamictons in these intervals suggest that the primary sand modes are depositional or from winnowing, and not a reworked signature derived from the source sediment. Stratification and heterogeneous particle size distributions with sand enrichments characterize glaciomarine diamicts elsewhere on high latitude continental shelves (Licht et al. 1999, Principato et al. 2005) and current activity and iceberg scouring are processes that have affected diamictons outcropping at the sea floor in this area during the current interglacial (Beaman \& Harris 2003). In support of our interpretation, the glaciomarine diamictons in section 2R-1 and 4R-1 display elevated Ba-excess values (Fig. 2b) indicative of increased primary productivity (Schenau et al. 2001). The inclined bedding of the stratified diamicton in section 3R-3 (Fig. 2) may signal iceberg scouring or a transition to more ice-proximal conditions, as discussed below.

The massive diamictons between $\sim 9$ mb.s.f. and $20.45 \mathrm{~m}$ b.s.f. (bottom of core $2 \mathrm{R}$ and most of core $3 \mathrm{R}$ ) were initially interpreted as subglacial deposits with possible remobilization by debris flows (Expedition 318 Scientists 2011). The uniform particle size distributions for the deposits in section $2 \mathrm{R}-\mathrm{CC}$ and core $3 \mathrm{R}$ confirm the shipboard interpretations of subglacial deformation and debris flow as the dominant diamicton forming process (Licht et al. 1999, Passchier et al. 2003, Principato et al. 2005). Contemporaneous, sparse, diatom assemblages reworked into the tills in core $3 \mathrm{R}$, however, are indicative of open-marine conditions (Expedition 318 Scientists 2011). Whereas the massive diamictons demonstrate that ice advanced to the outer shelf or shelf break during glacials of some part of the early Pliocene, the sparse diatoms reworked into these diamictons may represent retreat and open marine conditions during interglacials.

\section{Sediment provenance}

In shelf drill-cores, sand provenance studies can reveal valuable information on major changes in the loci of glacial erosion. From protolith/rock type pie diagrams (Fig. 3d), we observe a shift in provenance from a contribution from metapelitic rocks of the staurolite-sillimanite facies, and high mafic granulite-amphibolite rocks in samples from cores $4 \mathrm{R}$ and $3 \mathrm{R}$, whereas samples from cores $2 R$ and1 $R$ show an increase in the contribution from mafic greenschist rocks of prehnite-pumpellyite facies. A mafic igneous component remains constant throughout all sample intervals. The amphiboles (kaersutite, actinolite, hornblende, and cummingtonite/grunerite) point to a large contribution from high/intermediate grade metamorphic rocks (Fig. 5). 


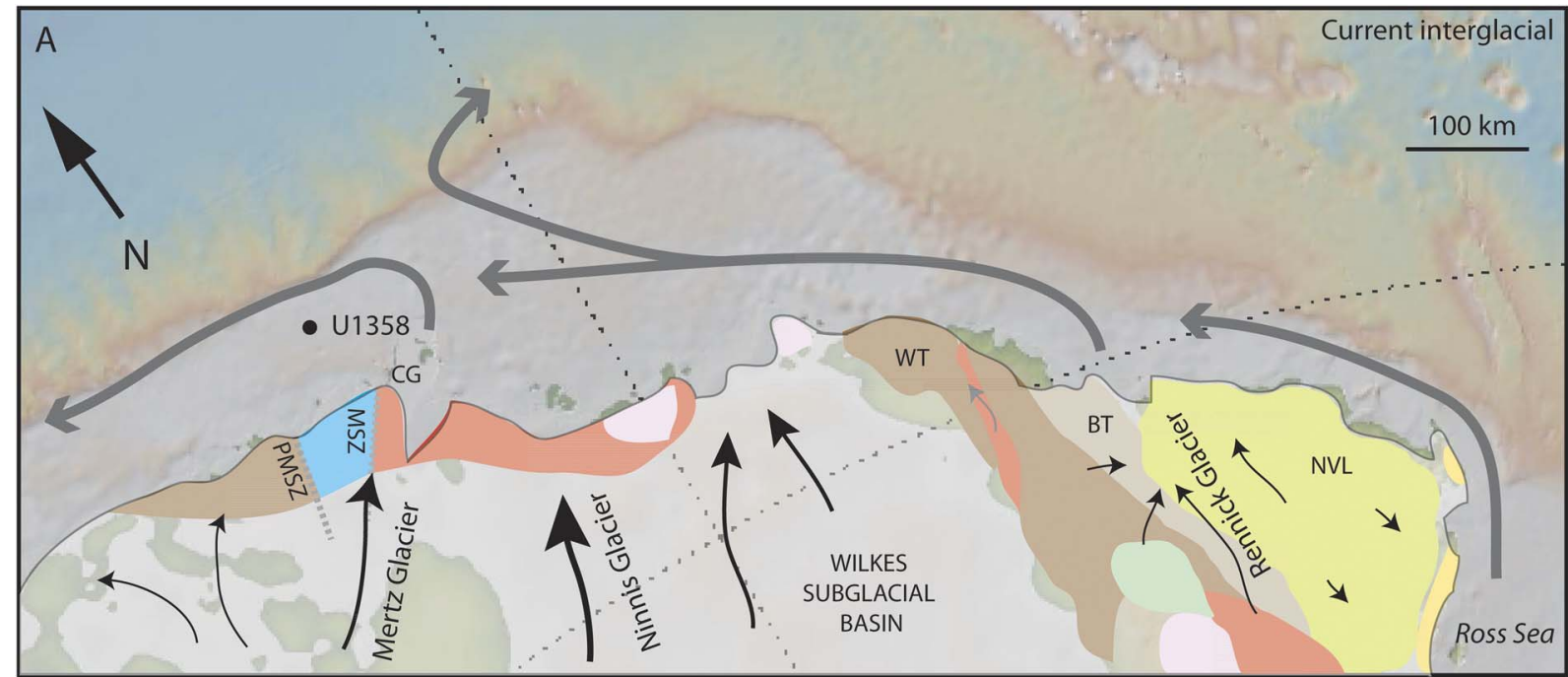

LEGEND

Archean metapelites and granitoids (granulite)

Precambrian metasediments (amphibolite)

Precambrian mafic volcanic and sedimentary (greenschist)

Precambrian greywackes and argillites

"u,u,u, Tectonic shear zone

Paleozoic granitoid instrusives

Beacon Supergroups sedimentary rocks

Jurassic mafic igneous dikes and sills

Cenozoic alkaline volcanics
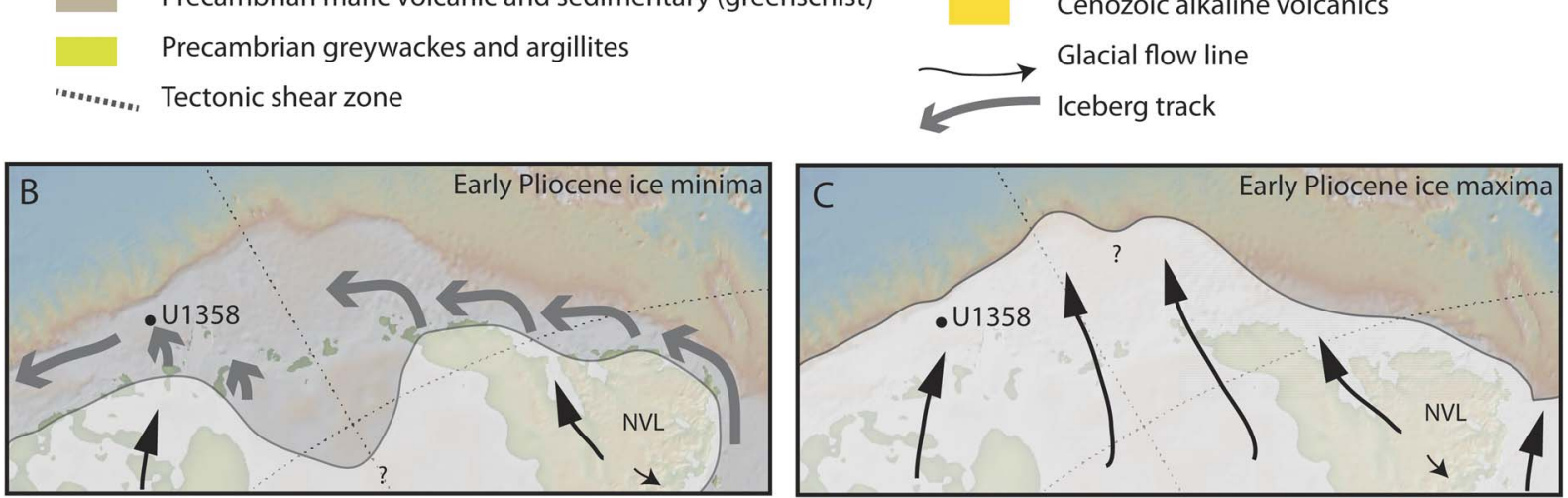

Fig. 6. a. Geological sketch map of East Antarctica with location of Integrated Ocean Drilling Program (IODP) site U1358 on the George V continental shelf overlain on bed topography and palaeobathymetry. Geology based on Gair et al. (1969), Wodzicki \& Robert (1986), Oliver \& Fanning (2002), and Goodge \& Fanning (2010). NVL = northern Victoria Land, BT = Bowers Terrane, WT $=$ Wilson Terrane, CG = Cape Gray, MSZ = Mertz Shear Zone, PMSZ = Port Martin Shear Zone. Bed topography and palaeobathymetry was plotted using GeoMap App (http://www.geomapapp.org) based on a data compilation of Ryan et al. (2009). Green areas are bed topography above sea level, the continental shelf is tan to pink, the continental slope orange, the continental rise is yellow, and the abyssal plain is blue. Iceberg tracks are based on satellite observations of Stuart \& Long (2011). b. Scenario for sediment delivery during glacial minima during the early Pliocene with more icebergs melting near their source due to warm ocean temperatures. c. Scenario for sediment delivery during glacial maxima of the early Pliocene with ice extending to the shelf break supplying sand with local provenance.

The presence of cummingtonite and grunerite suggests that the amphiboles carry a Wilkes Land basement signature (Oliver \& Fanning 2002, Goodge \& Fanning 2010). Pyroxenes, possibly derived from basement granodiorites and/or the Ferrar Group, were identified throughout the core but comprise a negligible overall contribution to the heavy mineral assemblages in the fine sand fraction.

Specific U1358 mineral assemblages (Table S3, which will be found at http://dx.doi.org/10.1017/S0954102013000527) are indicative of the Archean metapelites and metagranitoids found in the region bounded by the Port Martin and Mertz Shear Zones (Oliver \& Fanning 2002, Goodge \& Fanning 2010). This cratonic terrane (Fig. 6) also contains mafic dyke intrusions, mafic granulite/amphibolite metamorphosed rocks, and marbles. Mineral assemblages, however, also identify a low-grade metamorphic rock (prehnite-pumpellyite facies), which resembles rock types found in outcrop far to the east in the Bowers Terrane of northern Victoria Land and Oates 
Coast (Wodzicki \& Robert 1986). Wet-based ice discharging into Rennick Glacier covered this area until the late Miocene, followed by exposure and soil production (Mayewski et al. 1979, Van de Wateren et al. 1999). A more recent ice re-advance across this soil mantle led to the Rennick Glacier grounding line extending c. $43 \mathrm{~km}$ northward, followed by another, still ongoing, thinning and retreat (Mayewski et al. 1979, Pritchard et al. 2009). Whereas material from this source area is a subordinate component in samples of cores $3 R$ and $4 R$, its relative abundance is increased in the samples of core $2 \mathrm{R}$. Hence, we postulate a change in source rock for the fine sand fraction within core $2 R$ with the loci of sediment delivery through glacial erosion migrating eastward.

\section{Palaeoclimatological implications}

Diatom assemblages provide tentative age control for hole U1358B (Expedition 318 Scientists 2011; Table S4, which will be found at http://dx.doi.org/10.1017/S0954 102013000527). Based on the presence of Thalassiosira antarctica Comber, core $1 \mathrm{R}$, the upper $0.42 \mathrm{~m}$ b.s.f., is assigned to the latest Pleistocene-Holocene $(<0.61 \mathrm{Ma})$, with the absence of Actinocyclus ingens Ratray with last occurrence (LO) at $0.54 \mathrm{Ma}$ possibly constraining this interval to within the last $\sim 540 \mathrm{ky}$. A condensed interval or a hiatus was inferred in core $2 \mathrm{R}$ at $\sim 9 \mathrm{~m}$ b.s.f. Based on the presence of Thalassiosira inura Gersonde (2.54-4.74 Ma) and Thalassiosira torokina Brady (2.24-7.23 Ma), and the absence of Thalassiosira lentiginosa (Janisch) Fryxell with first occurrence (FO) at $3.99 \mathrm{Ma}$ and Fragilariopsis curta (van Heurck) Hustedt (FO at 3.56 Ma), the strata recovered in the interval below the hiatus ( $\sim 9$ m b.s.f in section $2 \mathrm{R}-1)$ are tentatively assigned an early Pliocene age.

The interval of no deposition or hiatus at $\sim 9 \mathrm{mb}$.s.f. ( $>3.99 \mathrm{Ma}$ to $<0.61 / 0.54 \mathrm{Ma}$ ) in U1358B overlaps with a widespread erosion surface (pp-12) with tentative age of 3.9-3.6 Ma on the Prydz Bay continental shelf (O'Brien et al. 2007) and a hiatus ( $>4.2 \mathrm{Ma}$ to $<3.4 \mathrm{Ma})$ within a diatomite in the AND-1B core marking an erosion or non-deposition event during full deglaciation of the Ross Sea (Naish et al. 2009). The age control for the drill-holes mentioned here, however, is not sufficient to evaluate whether the erosion surfaces are coeval and the erosion surfaces are not directly correlated in seismic data.

Interestingly, we observe a significant change in provenance across the condensed interval or hiatus. Moreover, the sediment matrix of the diamicton sampled at $9.03 \mathrm{mb}$.s.f. in U1358B, which coincides with the hiatus, has an anomalous major and trace element composition and a bimodal grain-size distribution with a primary fine-sand mode consistent with sediment sorting and winnowing. SEM analysis revealed the presence of abundant biogenic pyritized sediment clasts suggestive of local scouring and winnowing of a substrate of biogenic sediments (Fig. 5).
Two different scenarios, or a combination of the two, explain the observed changes in diamicton sedimentology and sand provenance. First, variation in sand provenance may reflect a change in ice-flow direction, with sediment delivery directly by ice from more easterly sources during the Pleistocene compared to the Pliocene. Second, the data may reflect changes in sand delivery via iceberg rafting during interglacial conditions, with this sand fraction then being reworked into the diamicton upon glacial advance of the Mertz Glacier system.

Today, most icebergs follow the counter-clockwise path of the Antarctic coastal current (Stuart \& Long 2011). For the lower Pliocene glaciomarine strata (core 4R), the local signature of the sand provenance suggests low iceberg supply or survival rates from eastern sources, consistent with a somewhat retreated ice margin (Fig. 6b) and higher early Pliocene sea surface temperatures in the Southern Ocean (Whitehead \& Bohaty 2003, Escutia et al. 2009). Diatom assemblages suggest a periodic high-nutrient, open-water environmental setting, similar to that of the modern-day Southern Ocean north of the winter sea ice extent (Expedition 318 Scientists 2011). In contrast, the local provenance of the ice-contact diamictons in core $3 \mathrm{R}$ is indicative of shelf-wide ice advances by the Mertz Glacier during the early Pliocene (Fig. 6c). Together, the sedimentological, diatom, and geochemical evidence suggests that the ice sheet may have lifted off the bed and stayed in a more stable retreated position during some portion of the early Pliocene (core 4R) with advances to shelf break at a later time in the early Pliocene (core 3R).

For the Pleistocene (cores 2R-1R), the increase in subglacial transport of sand from as far away as the Bowers Terrane would require unrealistically long glacial flow lines parallel to the coast and originating from Rennick Glacier (Fig. 6a). It is also noteworthy that the $\mathrm{Al}_{2} \mathrm{O}_{3} / \mathrm{TiO}_{2}$ ratios for the matrix of the diamictons remain constant throughout U1358 indicating little change in the provenance for the mud fraction (Fig. 3b). Given the distant location, a transport path for the sand fraction via iceberg rafting during interglacials seems more plausible. The increase in far-travelled material can be explained by the Late Pliocene decrease in sea surface temperatures in the Southern Ocean and an increase in iceberg survival rates (Whitehead \& Bohaty 2003, Escutia et al. 2009). A Pleistocene configuration (cores $2 \mathrm{R}$ and $1 \mathrm{R}$ ) with sand transport from the east is roughly in agreement with the previously predicted path of the last ice advance across the continental shelf in this area (Domack 1982). However, based on a further increase in far-travelled sand-sized detritus originating from the Bowers Terrane, we also infer interglacial ice-rafting as a probable sediment transport mechanism for a portion of the sand fraction in the Late Pleistocene sediments.

In summary, during the early Pliocene a dynamic marine-based ice sheet retreated from the Wilkes Land 
continental shelf with periodic ice advances to the outer shelf beyond the LGM position. A change in sand provenance is indicative of a more stable Mertz Glacier system during the Late Pleistocene $(<0.54 \mathrm{Ma})$ with a larger proportion of sand delivered by ice rafting.

\section{Conclusions}

1) Pliocene-Pleistocene Wilkes Land margin diamictons are chemically unweathered with subglacial deformation and debris flow being the dominant forming process for the lower Pliocene diamictons in core 3R, whereas deposition from floating ice produced the lower Pliocene and Upper Pleistocene diamictons in cores 4R, 2R and $1 \mathrm{R}$.

2) The sand provenance of the diamictons had a primarily local signature in the early Pliocene with an increase of a more distant source in northern Victoria Land during the Pleistocene suggestive of a more complex sediment delivery pathway.

3) The sedimentological and stratigraphic evidence is consistent with a dynamic ice margin with some retreat during the early Pliocene ( $>3.99 \mathrm{Ma}$ ) with ice advances delivering local debris from the Mertz Glacier system to the outer shelf or shelf break. In contrast, a more stable ice margin is envisioned for the Late Pleistocene $(<0.54 \mathrm{Ma})$ with a decrease in the delivery of locally derived glacial debris and an increase in far-travelled ice-rafted material.

\section{Acknowledgements}

This research was supported by a shipboard salary and post-expedition activities award (\# IUSSP410-T318A72) administered by the Consortium for Ocean Leadership, the National Science Foundation (award \# OCE 1060080), and an undergraduate research award through the SHIP program at Montclair State University (sponsored by the Merck and Roche Foundation). Samples were provided by the Integrated Ocean Drilling Program. We thank the reviewers of this paper, Claus-Dieter Hillenbrand and Julie Brigham-Grette, for their valuable and insightful contributions.

\section{Supplemental material}

Two supplemental figures and four supplemental tables will be found at http://dx.doi.org/10.1017/S0954102013000527.

\section{References}

Beaman, R.J. \& Harris, P.T. 2003. Seafloor morphology and acoustic facies of the George V Land shelf. Deep-Sea Research II, 50, $1343-1355$.
Beaman, R.J., O’Brien, P.E., Post, A.L. \& De Santis, L. 2011. A new high-resolution bathymetry model for the Terre Adélie and George V continental margin, East Antarctica. Antarctic Science, 23, 95-103.

Benn, D.I. \& Gemmell, A.M.D. 2002. Fractal dimensions of diamictic particle-size distributions: simulations and evaluation. Geological Society of America Bulletin, 114, 528-532.

Deer, W.A., Howie, R.A. \& Zussman, J. 1992. An introduction to the rock forming minerals, 2nd ed. London: Longman, $696 \mathrm{pp}$.

Dомаск, E.W. 1982. Sedimentology of glacial and glacial marine deposits on the George V-Adélie continental shelf, East Antarctica. Boreas, 11, 79-97.

Escutia, C., Bárcena, M.A., Lucchi, R.G., Romero, O., Ballegeer, A.M., Gonzalez, J.J. \& HaRwood, D.M. 2009. Circum-Antarctic warming events between 4 and 3.5 Ma recorded in marine sediments from the Prydz Bay (ODP Leg 188) and the Antarctic Peninsula (ODP Leg 178) margins. Global and Planetary Change, 69, 170-184.

Escutia, C., De Santis, L., Donda, F., Dunbar, R.B., Cooper, A.K., Brancolini, G. \& Eittreim, S.L. 2005. Cenozoic ice sheet history from East Antarctic Wilkes Land continental margin sediments. Global and Planetary Change, 45, 51-81.

Escutia, C., Brinkhuis, H., Klaus, A. \& The Expedition 318 Scientists 2011. Proceedings of the Integrated Ocean Drilling Program, 318, 10.2204/iodp.proc.318.101.2011.

Expedition 318 Scientists 2011. Site U1358. In Escutia, C., Brinkhuis, H., Klaus, A. \& The Expedition 318 Scientists. Integrated Ocean Drilling Program Proceedings, 318, 10.2204/iodp.proc.318.106.2011.

Fretwell, P., Pritchard, H.D., Vaughan, D.G., et al. 2013. Bedmap2: improved ice bed, surface and thickness datasets for Antarctica. The Cryosphere, 7, 375-393.

Gair, H.S., Sturm, A., Carryer, S.J. \& Grindley, G.W. 1969. The geology of northern Victoria Land. Geologic map of Antarctica, sheet 13, plate XII. Antarctic Map Folio Series, 12.

Goodge, J.W. \& Fanning, C.M. 2010. Composition and age of the East Antarctic Shield in eastern Wilkes Land determined by proxy from Oligocene-Pleistocene glaciomarine sediment and Beacon Supergroup sandstones, Antarctica. Geological Society of America Bulletin, 122, $1135-1159$.

Hooke, R.LeB. \& Iverson, N.R. 1995. Grain size distribution in deforming subglacial tills: role of grain fracture. Geology, 23, 57-60.

Konert, M. \& VAndenberghe, J. 1997. Comparison of laser grain size analysis with pipette and sieve analysis: a solution for the underestimation of the clay fraction. Sedimentology, 44, 523-535.

Licht, K.J., Dunbar, N.W., Andrews, J.T. \& Jennings, A.E. 1999. Distinguishing subglacial till and glacial marine diamicts in the western Ross Sea, Antarctica: implications for a last glacial maximum grounding line. Geological Society of America Bulletin, 111, 91-103.

Mayewski, P.A., Attig, J.W. \& Drewry, D.J. 1979. Pattern of ice surface lowering for the Rennick Glacier, northern Victoria Land, Antarctica. Journal of Glaciology, 22, 53-65.

McLennan, S.M., Hemming, S., McDaniel, D.K. \& Hanson, G.N. 1993. Geochemical approaches to sedimentation, provenance and tectonics. Geological Society of America Special Paper, 284, 21-40.

Murray, R.W., Miller, D.J. \& Kryc, K.A. 2000. Analysis of major and trace elements in rocks, sediments, and interstitial waters by inductively coupled plasma-atomic emission spectrometry (ICP-AES). ODP Technical Note, 29. Available at http://www-odp.tamu.edu/publications/ tnotes/tn29/INDEX.HTM, accessed September 2012.

Naish, T., Powell, R., Levy, R., et al. 2009. Obliquity-paced Pliocene West Antarctic Ice Sheet oscillations. Nature, 458, 322-328.

Nesbitt, H.W. \& Young, G.M. 1982. Early Proterozoic climates and plate motions inferred from major element chemistry of lutites. Nature, 199, $715-717$.

Nesbitt, H.W. \& Young, G.M. 1996. Petrogenesis of sediments in the absence of chemical weathering: effects of abrasion and sorting on bulk composition and mineralogy. Sedimentology, 42, 341-358. 
O’Brien, P.E., Goodwin, I., Forsberg, C.-F., Cooper, A.K. \& Whitehead, J. 2007. Late Neogene ice drainage changes in Prydz Bay, East Antarctica and the interaction of Antarctic ice sheet evolution and climate. Palaeogeography, Palaeoclimatology, Palaeoecology, 245, 390-410.

Oliver, R.L. \& FAnNing, C.M. 2002. Proterozoic geology east and southeast of Commonwealth Bay, George V Land, Antarctica, and its relationship to that of adjacent Gondwana terranes. Royal Society of New Zealand Bulletin, No. 35, 51-58.

Passchier, S., O’Brien, P.E., Damuth, J.E., Januszczack, N., Handwerger, D.A. \& WhiteheAD, J.M. 2003. Pliocene-Pleistocene glaciomarine sedimentation in eastern Prydz Bay and development of the Prydz trough-mouth fan, ODP sites 1166 and 1167, East Antarctica. Marine Geology, 199, 179-305.

Principato, S.M., Jennings, A.E., Kristjansdottir, G.B. \& Andrews, J.T. 2005. Glacial-marine or subglacial origin of diamicton units from the southwest and north Iceland shelf: implications for the glacial history of Iceland. Journal of Sedimentary Research, 75, 968-983.

Pritchard, H.D., Arthern, R.J., Vaughan, D.G. \& Edwards, L.A. 2009. Extensive dynamic thinning on the margins of the Greenland and Antarctic ice sheets. Nature, 461, 971-975.

REED, S.J.B. 2005. Electron microprobe analysis and scanning electron microscopy in geology. 2nd edition. New York: Cambridge University Press, $162-178$.
Ryan, W.B.F., Carbotte, S.M., Coplan, J.O., et al. 2009. Global multiresolution topography synthesis. Geochemistry Geophysics Geosystems, 10.1029/2008GC002332.

Schenau, S.J., Prins, M.A., Delange, G.J. \& Monnin, C. 2001. Barium accumulation in the Arabian Sea: controls on barite preservation in marine sediments. Geochimica et Cosmochimica Acta, 65, 1545-1556.

Sperazza, M., Moore, J.N. \& Hendrix, M.S. 2004. High-resolution analysis of naturally occurring very fine-grained sediment through laser defractometry. Journal of Sedimentary Research, 74, 736-743.

Stuart, K.M. \& Long, D.G. 2011. Tracking large tabular icebergs using the SeaWinds Ku-band microwave scatterometer. Deep-Sea Research II, 58, 1285-1300.

Van der Wateren, F.M., Dunai, T.J., van Balen, R.T., Klas, W., Verbers, A.L.L.M., Passchier, S. \& Herpers, U. 1999. Contrasting Neogene denudation histories of different structural regions in the Transantarctic Mountains rift flank constrained by cosmogenic isotope measurements. Global and Planetary Change, 23, 145-172.

Whitehead, J.M. \& Bohaty, S.M. 2003. Pliocene summer sea surface temperature reconstruction using silicoflagellates from Southern Ocean ODP site 1165. Paleoceanography, 10.1029/2002PA000829.

Wodzicki, A. \& Robert, R. 1986. Geology of the Bowers Supergroup, central Bowers Mountains, northern Victoria Land. Antarctic Research Series, 46, 39-68. 